\title{
Fish farming in cages: a practice to be restricted in Brazil
}

\author{
Produção de peixes em tanques-rede: uma prática a ser restrita no Brasil
}

\section{Antonio Fernando Monteiro Camargo ${ }^{1,2 *}$ (D) and Rafael Vieira Amorim² (D)}

${ }^{1}$ Departamento de Ecologia, Instituto de Biociências, Universidade Estadual Paulista - UNESP, Av. 24A, 1515, CEP 13506-900, Rio Claro, SP, Brasil

${ }^{2}$ Programa de Pós-graduação em Aquicultura, Centro de Aquicultura, Universidade Estadual Paulista - UNESP, Via de acesso Prof. Paulo Donato Castellane, s/n, CEP 14884-900, Jaboticabal, SP, Brasil

*e-mail: antoniofmcamargo@gmail.com

Cite as: Camargo, A.F.M. and Amorim, R.V. Fish farming in cages: a practice to be restricted in Brazil. Acta Limnologica Brasiliensia, 2020, vol. 32, e101.

Abstract: World aquaculture has been growing sharply in recent decades and Brazilian production of fish in cages has grown considerably since the end of the 1990s. This increase is related to the development of federal government regulations and the large number of medium and large hydroelectric reservoirs. The main areas of fish production in cages in Brazil are currently located in the Northeast and Southeast regions and along the Southeast/South border. Tilapia production in cages in Brazil, as well as other species produced in cages in other regions of the world, has economic advantages for the producer. On the other hand, limnologically, tilapia production in cages causes enormous damage, as it promotes the process of artificial eutrophication and, possibly, introduces this exotic species. One way of reducing artificial eutrophication is the use of Integrated Multi-trophic Aquaculture (IMTA); however, its use in fish cages installed in Brazilian reservoirs is not possible yet. Therefore, our view is that government agencies restrict the production of fish in cages to the utmost.

Keywords: tilapia production; Brazilian reservoirs; limnological negative impacts; artificial eutrophication; good management practices.

Resumo: A aquicultura mundial vem crescendo acentuadamente nas últimas décadas e no Brasil a produção de peixes em tanques-rede teve grande crescimento a partir do final dos anos 90 . O aumento da produçáo de peixes em tanques-rede está relacionado ao desenvolvimento de normativas pelo Governo Federal e à grande quantidade de reservatórios de médio e grande porte para a geração de energia elétrica. Atualmente, os principais polos de produção de peixes em tanques rede no Brasil estão localizados nas regiôes nordeste, sudeste e no limite da região sudeste e sul. A criação de Tilápia em tanques-rede no Brasil, assim como outras espécies em outras regióes do mundo, tem vantagens econômicas para o produtor. Por outro lado, quanto ao aspecto limnológico, o cultivo de Tilápia em tanques-rede traz enormes prejuízos promovendo o processo de eutrofizaçáo artificial, além da possibilidade de introdução dessa espécie exótica. Uma maneira de reduzir a eutrofização artificial é a utilização de sistemas multitróficos (Integrated multi-trophic aquaculture - IMTA), no entanto, nos tanques-rede instalados em reservatórios brasileiros a utilizaçấo de IMTA ainda não é possível. Portanto, nossa opiniáo é a de que os órgãos governamentais restrinjam ao máximo a aquicultura em tanques-rede.

Palavras-chave: produção de tilápias; reservatórios brasileiros; impactos limnológicos negativos; eutrofização artificial; boas práticas de manejo. 


\section{Aquaculture Production}

Aquaculture has increased markedly in recent decades, while the capture of aquatic organisms has stabilized since about the early 1990s. In 2016, world capture of aquatic organisms was 90.9 million tons and world aquaculture production 80.0 million tons (FAO, 2018). The production of aquatic organisms can be carried out using different species in different systems and types of aquatic environments. Among the production systems, fish cages have been used on a global scale (Ramos et al., 2014; Keeley et al., 2014; Cai et al., 2016; Urbina, 2016; Tomassetti et al., 2016; Adhikari et al., 2017; Salvo et al., 2017) and with different fish species (Mallasen et al., 2012; Urbina, 2016; Milne et al., 2017; Srithongouthai \& Tada, 2017). This technology has been deployed in natural (Degefu et al., 2011; Price et al., 2015; White et al., 2017) and artificial (Nyanti et al., 2012; Montanhini Neto et al., 2017) aquatic environments.

\section{Production of Fish in Cages in Brazil}

In Brazil, the production of fish in cages began in the 1980s mainly in the state of São Paulo (Ayroza et al., 2006). However, the great growth of this activity in reservoirs only occurred in the late 1990s. This was due to technological advances and the fall in fish production in earthen ponds because of structural aspects of the production chain (Ayroza et al., 2006). In 1999, some regions of the state of São Paulo had about 500 fish cages installed in 25 properties (Kubo, 2005). At the beginning of the 2000s, about 30 aquaculture areas were installed only in the region of the middle Paranapanema River, with a total of 800 fish cages and an average tilapia production between 100 and $200 \mathrm{~kg} . \mathrm{m}^{-3}$ per cycle (Ayroza et al., 2006). Production of fish in cages increased in this period right after the federal government established regulatory standards regarding the use of public waters for aquaculture (Brasil, 2003, 2004, 2005a, b, 2009). The large number of medium and large hydroelectric reservoirs in Brazil (Perbiche-Neves \& Camargo, 2018) also contributed to its expansion. The installation of net cages is feasible in more than 250 hydroelectric reservoirs (Araújo et al., 2017).

The main areas that produce fish in cages in Brazil are currently located in the Northeast and Southeast regions and along the Southeast/South border. In the Northeast region, production has been carried out in reservoirs of the São Francisco River (state of Bahia) and in the large reservoirs
(Castanhão, Orós and Sítios Novos) located in the state of Ceará (Sussel, 2011). In the Southeast region, the largest center is located in the state of Sáo Paulo, especially in the northwestern part of the state, in reservoirs of the Paraná, Grande and lower Tietê Rivers (Sussel, 2011). Along the Southeast/South border, cultivation takes place in the reservoirs of the Paranapanema River (Ayroza et al., 2013).

Although several native species from Brazil are produced in cages, such as jundiá (Rhamdia quelen), pacu (Piaractus mesopotamicus) and curimbatá (Prochilodus lineatus), the most cultivated species is tilapia (Oreochromis niloticus) an exotic species from Africa that began to be commercially produced in Brazil in the 1980s in earthen ponds. Tilapia production in Brazil in 2018 was 400,228 tons, which corresponds to $55.4 \%$ of the total fish produced and was $11.9 \%$ higher than the previous year (PeixeBR, 2019). This production is concentrated in the states of Santa Catarina, Paraná, São Paulo, Minas Gerais and Bahia, but the production of tilapia in cages is higher in the states of São Paulo and Bahia. The states of Tocantins and Mato Grosso authorized the production of tilapia in cages in 2018. On the other hand, the production of native species decreased by $4.7 \%$ and is concentrated in the states of Acre, Rondônia, Pará, Maranhão and Mato Grosso (PeixeBR, 2019).

The expressive production of tilapia and the growth of production in cage occurs due to its technological production package being well developed and also due to its good acceptance in the national and international consumer market. Thus, the production of tilapia in cages in Brazil has better economic advantages for the producer. The same is true as regards other caged species in other regions of the world. The production of fish in cages is more economically viable for some species of marine fish and can also be more profitable (Beveridge, 2004).

\section{Limnological Perspective}

The production of fish in cages, on the other hand, causes enormous limnological damage, as it is an intensive production system, using high stocking densities and demanding a high amount of feed. Therefore, fish feed, feces and excretes are released into the water and partly deposited in the sediment. Montanhini Neto \& Ostrensky (2015) based on a bibliographic survey, estimated that for each ton of tilapia produced, approximately $1,043 \mathrm{~kg}$ of organic matter, $44.95 \mathrm{~kg}$ of N and $14.26 \mathrm{~kg}$ of $\mathrm{P}$ are released into the aquatic environment. 
Moura et al. (2014) observed a sedimentation rate of particulate material 18.5 times higher in areas with cages compared to the sedimentation rate of an area without a cage. In addition to local impacts, changes can occur in areas far from the cages. A study developed in a branch of the Ilha Solteira reservoir (northwestern part of the state of São Paulo) showed that the production of tilapia in cages can increase the concentrations of total nitrogen and total phosphorus in water up to $800 \mathrm{~m}$ away from the center of the farm (Amorim, 2018). Studies on the impacts caused by the cultivation of fish in cages in Brazil are restricted to tilapia farming and were mostly developed in the State of São Paulo, however, they serve as a warning for the use of this farming technique in other regions and for other species of fish. The increase in sedimentation of organic matter and the concentration of nutrients, also occurs in the cultivation in cages of marine species in different parts of the world (see Morata et al., 2015; Srithongouthai \& Tada., 2017; Lima et al., 2019). Therefore, what causes impact and promotes artificial eutrophication is the management and the system used.

In addition to causing eutrophication, the escape of animals is another problem related to the production of fish in cages. The production of exotic species is especially disturbing and it conflicts with the Aichi Biodiversity Targets, of which Brazil is a signatory. This is astonishing because it is a country with extraordinary aquatic biodiversity (Lima Junior et al., 2018). It is also important to highlight that the creation of fish in net cages is a source of changes in the fish community in neotropical reservoirs. In fact, Nobile et al. (2018) demonstrated that the presence of net cages increases the abundance and biomass of a few species that contribute to decrease richness and diversity.

The problem of introducing exotic species can be solved by raising native fish, but it does not solve the problems of eutrophication and alteration of the fish community. An alternative to reduce eutrophication caused by fish farming in net cages is the use of Integrated multi-trophic aquaculture (IMTA). IMTA combines two or more species with different trophic levels and positions in the water column in a single system (Chopin \& Robinson, 2004). Usually on these systems, two species of fish may be used inside the cages (e.g. herbivorous and detritivorous). The detritivorous species feeds on the leftover feed and feces of the herbivorous species. Species of filter-feeding mollusks that feed on fine particulate matter can be produced near fish cages. Substrates colonized by algae can also be installed near fish cages to remove inorganic nutrients (see Chopin et al., 2008).

However, IMTA cannot be used in fish cages installed in Brazilian reservoirs for technical reasons, for example, since there is no commercial freshwater mollusks species with established culture technology. In addition, floating aquatic macrophytes can be used to efficiently treat aquaculture effluents in earthen ponds (Santos \& Camargo, 2015; Osti et al., 2018), removing the nutrients in the surface portion of the water column, however, probably they will not efficiently remove nutrients produced by net cages that have been installed a minimum deep of 2.0 meters approximately. We emphasize that polycultures in Brazil, using species with different feeding habits, are only used in earthen ponds with the same concepts of IMTA systems. Thus, several studies have shown that polyculture systems in earthen ponds can make economic, productive and environmental benefits (David et al., 2017; Rodrigues et al., 2019a, b).

We are also apprehensive as regards the priority that different countries give to environmental conservation and the exploitation of natural resources for food production. While rich European countries restrict the production of aquatic organisms because they prioritize environmental conservation, poor countries like Brazil prioritize production. In Brazil, resolutions of the National Environmental Council (Conselho Nacional do Meio Ambiente) (CONAMA) deal with the environmental licensing of aquaculture and establish that freshwater activity can only be carried out in class II water. The upper limit of total phosphorus for class II is $30 \mu \mathrm{g} . \mathrm{L}^{-1}$, according to CONAMA Resolution 357 . However, CONAMA Resolution 413, which lays down aquaculture licensing standards, has no information on the procedure to be adopted if the phosphorus concentration exceeds the class II limit. Thus, if fish breeding in a licensed area promotes an increase in total phosphorus beyond the class II limit, no action will be taken and the eutrophication will increase in the environment without any consequences to the fish producers. In addition, Brazilian law has not established a detailed water quality monitoring plan (including frequency of water sampling) and does not encourage environmental awareness in fish producers. On the other hand, rich nations can reduce food production to conserve the environment by increasing imports and shifting environmental impact to countries with limited environmental controls. The United States, for 
example, is the largest importer of tilapia produced in Brazil. In 2018, more than 700 tons of tilapia were exported to this country (PeixeBr, 2019). World aquaculture growth is a reality and, on one level, it is very positive, as it supplies a demand for highly nutritional food and preserves fish stocks. However, this growth causes negative impacts on aquatic ecosystems, promoting artificial eutrophication and the possibility of exotic species introduction. Practices that reduce negative impacts (good management) should be rigorously implemented (several techniques are available) (see Henares et al., 2019), but only in fish production in earthen ponds, because freshwater cages still have many limitations. Our opinion, therefore, is that government agencies encourage aquaculture in earthen ponds and restrict it to the utmost in fish cages.

\section{References}

ADHIKARI, P.L., SHRESTHA, S., BAM, W., XIE, L. and PERSCHBACHER, P. Evaluation of spatialtemporal variations of water quality and plankton assemblages and its relationship to water use in Kulekhani Multipurpose Reservoir, Nepal. Journal of Environmental Protection, 2017, 8(11), 1270-1295. http://dx.doi.org/10.4236/jep.2017.811079.

AMORIM, R.V. Efeitos do cultivo de tilápias em tanquesrede na qualidade de água e na sedimentação de $N$ e $P$ em área aquícola da usina hidrelétrica de Ilha Solteira, SP [Tese de Doutorado]. Jaboticabal: Universidade Estadual Paulista, 2018.

ARAÚJO, C.A.S., SAMPAIO, F.G., ALCÂNTARA, E., CURTARELLI, M.P., OGASHAWARA, I. and STECH, J.L. Effects of atmospheric cold fronts on stratification and water quality of a tropical reservoir: implications for aquaculture. Aquaculture Environment Interactions, 2017, 9, 385-403. http:// dx.doi.org/10.3354/aei00240.

ASSOCIAÇÃO BRASILEIRA DA PISCICULTURA PeixeBR. Anuário brasileiro da piscicultura. São Paulo: Texto Comunicação Corporativa, 2019.

AYROZA, D.M.M.R., FURLANETO, F.P.B. and AYROZA, L.M.S. Regularização dos projetos de tanques-rede em águas públicas continentais de dominio da união no Estado de São Paulo [online]. São Paulo: Instituto de Pesca, 2006. Boletim Técnico do Instituto de Pesca, no. 36 [viewed 26 Apr. 2019]. Available from: https://www.pesca.sp.gov.br/ boletim_tec_36.pdf

AYROZA, D.M.M.R., NOGUEIRA, M.G., AYROZA, L.M.S. and CARVALHO, , E.D., FERRAUDO, A.S. and CAMARGO, A.F.M. Temporal and spatial variability of limnological characteristics in areas under the influence of tilapia cages in the Chavantes Reservoir, Paranapanema River, Brazil. Journal of the
World Aquaculture Society, 2013, 44(6), 814-825. http://dx.doi.org/10.1111/jwas.12082.

BEVERIDGE, M.C.M. Cage aquaculture. 3rd ed. Oxford: Blackwell Publishing, 2004. http://dx.doi. org/10.1002/9780470995761.

BRASIL. Decreto n 4.895 de 25 de novembro de 2003. Dispóe sobre a Autorização de Uso de Espaços Físicos de Corpos d'água de Domínio da União para fins de Aquicultura, e dá outras providências. Diário Oficial da União [da] República Federativa do Brasil, Poder Executivo, Brasília, DF, 26 nov. 2003, Seção 1, p. 62.

BRASIL. Instrução normativa interministerial $n^{\circ} 6$ de 31 de maio de 2004. Estabelece as normas complementares para a autorização de uso dos espaços físicos em corpos d'água de domínio da União para fins de aquicultura, e dá outras providências. Diário Oficial da União [da] República Federativa do Brasil, Poder Executivo, Brasília, DF, 1 jun. 2004, Seção 1, p. 1253.

BRASIL. Resolução CONAMA n 357 de 17 de março de 2005. Dispóe sobre a classificação dos corpos de água e diretrizes ambientais para o seu enquadramento, bem como estabelece as condiçóes e padrôes de lançamento de efluentes, e dá outras providências (Revogou a Resolução CONAMA n 20, de 18 de junho de 1986). Diário Oficial da União [da] República Federativa do Brasil, Poder Executivo, Brasília, DF, 18 mar. 2005a, Seção 1, p. 58.

BRASIL. Instrução normativa interministerial $\mathrm{n}^{\circ} 7$ de 28 de abril de 2005. Estabelece diretrizes para implantação dos parques e áreas aquícolas. Diário Oficial da União [da] República Federativa do Brasil, Poder Executivo, Brasília, DF, 29 abr. 2005b, Seção 1, p. 1542.

BRASIL. Resolução CONAMA n 413 de 26 de junho de 2009. Estabelece normas e critérios para o licenciamento ambiental da aquicultura, e dá outras providências. Diário Oficial da União [da] República Federativa do Brasil, Poder Executivo, Brasília, DF, 30 jun. 2009, Seção 1, p. 126.

CAI, H., ROSS, L.G., TELFER, T.C., WU, C., ZHU, A., ZHAO, S. and XU, M. Modelling the nitrogen loadings from large yellow croaker (Larimichthys crocea) cage aquaculture. Environmental Science and Pollution Research International, 2016, 23(8), 7529. 7542. http://dx.doi.org/10.1007/s11356-015-60150. PMid:26728289.

CHOPIN, T. and ROBINSON, S. Defining the appropriate regulatory and policy framework for the development of integrated multi-trophic aquaculture practices: introduction to the workshop and positioning of the issues. Bulletin of the Aquaculture Association of Canada, 2004, 104(3), 4-10.

CHOPIN, T., ROBINSON, S.M.C., TROELL, M., NEORI, A., BUSCHMANN, A.H. and FANG, J. Multitrophic integration for sustainable marine 
aquaculture. In: S.E. JØRGENSEN and B.D. FATH, eds. The encyclopedia of ecology. 2nd ed. Oxford: Elsevier, 2008, pp. 2463-2475. vol. 3. http://dx.doi. org/10.1016/B978-008045405-4.00065-3.

DAVID, F.S., PROENÇA, D.C. and VALENTI, W.C. Nitrogen budget in integrated aquaculture systems with Nile tilapia and Amazon River prawn. Aquaculture International, 2017, 25(5), 1733-1746. http://dx.doi.org/10.1007/s10499-017-0145-y.

DEGEFU, F., MENGISTU, S. and SCHAGERL, $M$. Influence of fish cage farming on water quality and plankton in fish ponds: a case study in the Rift Valley and North Shoa reservoirs, Ethiopia. Aquaculture, 2011,316(1-4), 129-135. http://dx.doi. org/10.1016/j.aquaculture.2011.03.010.

FOOD AND AGRICULTURE ORGANIZATION OF THE UNITED NATION - FAO. The state of world fisheries and aquaculture: meeting the sustainable development goals [online]. Rome, 2018 [viewed 4 Feb. 2019]. Available from: http://www.fao.org/3/ i9540en/i9540en.pdf

HENARES, M.N.P., MEDEIROS, M.V. and CAMARGO, A.F.M. Overview of strategies that contribute to the environmental sustainability of pond aquaculture: rearing systems, residue treatment, and environmental assessment tools. Reviews in Aquaculture, 2019, 1, 1-18. http://dx.doi. org/10.1111/raq.12327.

KEELEY, N.B., MACLEOD, C.K., HOPKINS, G.A. and FORREST, B.M. Spatial and temporal dynamics in macrobenthos during recovery from salmon farm induced organic enrichment: when is recovery complete? Marine Pollution Bulletin, 2014, 80(1-2), 250-262. http://dx.doi.org/10.1016/j. marpolbul.2013.12.008. PMid:24503378.

KUBO, E. Tanque-rede é opção para produção continental de peixes [online]. São Paulo: Instituto de Pesca, 2005 [viewed 25 Apr. 2019]. Available from: https://www. pesca.sp.gov.br/tanque_rede.pdf

LIMA, L.S., PINTO, T.K., BRANDÁO, B.C.S., SANTOS, W., SANTIAGO, H., DOMINGUES, E.C., KLEIN, A.P., SCHETTINI, C.A., POERSCH, L.H. and CAVALLI, R.O. Impact of cage farming of cobia (Rachycentron canadum) on the benthic macrofauna in a tropical region. Aquaculture, 2019, 512(734314). http://dx.doi.org/10.1016/j. aquaculture.2019.734314.

LIMA JUNIOR, D.P., MAGALHĀES, A.L.B., PELICICE, F.M., VITULE, J.R.S., AZEVEDOSANTOS, V.M., ORSI, M.L., SIMBERLOFF, D. and AGOSTINHO, A.A. Aquaculture expansion in Brazilian freshwaters against the Aichi Biodiversity Targets. Ambio, 2018, 47(4), 427-440. http://dx.doi. org/10.1007/s13280-017-1001-z. PMid:29306998.

MALLASEN, M., CARMO, C.F., TUCCI, A., BARROS, H.P., ROJAS, N.E.T., FONSECA, F.S. and YAMASHITA, E.Y. Qualidade da água em sistema de piscicultura em tanques-rede no reservatório de Ilha Solteira, SP. Boletim do Instituto de Pesca, 2012, 38(1), 15-30.

MILNE, J.E., MARVIN, C.H., YERUBANDI, R., MCCANN, K. and MOCCIA, R.D. Monitoring and modelling total phosphorus contributions to a freshwater lake with cage-aquaculture. Aquaculture Research, 2017, 48(1), 283-297. http://dx.doi. org/10.1111/are.12881.

MONTANHINI NETO, R. and OSTRENSKY, A. Nutrient load estimation in the waste of Nile tilapia Oreochromis niloticus (L.) reared in cages in tropical climate conditions. Aquaculture Research, 2015, 2015(46), 1309-1322. http://dx.doi.org/10.1111/ are. 12280 .

MONTANHINI NETO, R., NOCKO, H.R. and OSTRENSKY, A. Carrying capacity and potential environmental impact of fish farming in the cascade reservoirs of the Paranapanema River, Brazil. Aquaculture Research, 2017, 48(7), 3433-3449. http://dx.doi.org/10.1111/are.13169.

MORATA, T., FALCO, S., GADEA, I., SOSPEDRA, J. and RODILLA, M. Environmental effects of a marine fish farm of gilthead seabream (Sparus aurata) in the NW Mediterranean Sea on water column and sediment. Aquaculture Research, 2015, 46(1), 59-74. http://dx.doi.org/10.1111/are.12159.

MOURA, R.S.T., LOPES, Y.V.A. and HENRYSILVA, G.G. Sedimentação de nutrientes e material particulado em reservatório sob influência de atividades de piscicultura no semiárido do Rio Grande do Norte. Revista Quimica Nova, 2014, 37(8), 1283-1288. http://dx.doi.org/10.5935/01004042.20140203 .

NOBILE, A.B., ZANATTA, A.S., BRANDÃO, H., ZICA, E.O.P., LIMA, F.P., FREITAS-SOUZA, D., CARVALHO, E.D., SILVA, R.J. and RAMOS, I.P. Cage fish farm act as a source of changes in the fish community of a Neotropical reservoir. Aquaculture, 2018, 495, 780-785. http://dx.doi.org/10.1016/j. aquaculture.2018.06.053.

NYANTI, L., HII, K.M., SOW, A., NORHADI, I. and LING, T.Y. Impacts of aquaculture at different depths and distances from cage culture sites in Batang Ai hydroelectric dam reservoir, Sarawak, Malaysia. World Applied Sciences Journal, 2012, 19, 451-456. http:// dx.doi.org/10.5829/idosi.wasj.2012.19.04.1340.

OSTI, J.A.S., HENARES, M.N.P. and CAMARGO, A.F.M. The efficiency of free-floating and emergent aquatic macrophytes in constructed wetlands for the treatment of a fishpond effluent. Aquaculture Research, 2018, 49(10), 3468-3476. http://dx.doi. org/10.1111/are.13813.

PERBICHE-NEVES, G. and CAMARGO, A.F.M. Editorial: reservoirs ecology. Acta Limnologica Brasiliensia, 2018, 30(0), 1-4. http://dx.doi. org/10.1590/s2179-975×3002018. 
PRICE, C., BLACK, K.D., HARGRAVE, B. and MORRIS JUNIOR, J.A. Marine cage culture and the environment: effects on water quality and primary production. Aquaculture Environment Interactions, 2015, 6(2), 151-174. http://dx.doi.org/10.3354/ aei00122.

RAMOS, I.P., FRANCESCHINI, L., ZICA, É.O.P., CARVALHO, E.D. and SILVA, R.J. The influence of cage farming on infection of the corvine fish Plagioscion squamosissimus (Perciformes: Sciaenidae) with metacercariae of Austrodiplostomum compactum (Digenea: Diplostomidae) from the Chavantes reservoir, São Paulo State, Brazil. Journal of Helminthology, 2014, 88(3), 342-348. http://dx.doi.org/10.1017/S0022149X13000229. PMid:23628163.

RODRIGUES, C.G., GARCIA, B.F., VERDEGEM, M., SANTOS, M.R., AMORIM, R.V. and VALENTI, W.C. Integrated culture of Nile tilapia and Amazon river prawn in stagnant ponds, using nutrient-rich water and substrates. Aquaculture, 2019a, 503, 111-117. http://dx.doi.org/10.1016/j. aquaculture.2018.12.073.

RODRIGUES, C.G., ENGLE, C., GARCIA NETO, B.F., AMORIM, R.V. and VALENTI, W.C. The effect of choice of targeted market, production scale, and land tenure on the economics of integrated tilapia-prawn production. Aquaculture Economics of Management, 2019b, 22(2), 1-14. http://dx.doi.org /10.1080/13657305.2018.1531951.

SALVO, F., MERSEREAU, J., HAMOUTENE, D., BELLEY, R. and DUFOUR, S.C. Spatial and temporal changes in epibenthic communities at deep, hard bottom aquaculture sites in Newfoundland. Ecological Indicators, 2017, 76, 207-218. http:// dx.doi.org/10.1016/j.ecolind.2017.01.019.

SANTOS, A.A.O. and CAMARGO, A.F.M. Constructed wetlands for treatment of harvest effluents from grow- out ponds of the Amazon river prawn. Aquaculture Research, 2015, 46(11), 2676-2684. http://dx.doi. org/10.1111/are.12423.

SRITHONGOUTHAI, S. and TADA, K. Impacts of organic waste from a yellowtail cage farm on surface sediment and bottom water in Shido Bay (the Seto Inland Sea, Japan). Aquaculture, 2017, 471, 140-145. http://dx.doi.org/10.1016/j. aquaculture.2017.01.021.

SUSSEL, F.R. Tilapicultura no estado de São Paulo. Pesquisa \& Tecnologia, 2011, 8(2), 1-4.

TOMASSETTI, P., GENNARO, P., LATTANZI, L., MERCATALI, I., PERSIA, E., VANI, D. and PORRELLO, S. Benthic community response to sediment organic enrichment by Mediterranean fish farms: case studies. Aquaculture, 2016, 450(1), 262-272. http://dx.doi.org/10.1016/j. aquaculture.2015.07.019.

URBINA, M.A. Temporal variation on environmental variables and pollution indicators in marine sediments under sea Salmon farming cages in protected and exposed zones in the Chilean inland Southern Sea. The Science of the Total Environment, 2016, 573, 841-853. http://dx.doi.org/10.1016/j. scitotenv.2016.08.166. PMid:27595942.

WHITE, C.A., NICHOLS, P.D., ROSS, D.J. and DEMPSTER, T. Dispersal and assimilation of an aquaculture waste subsidy in a low productivity coastal environment. Marine Pollution Bulletin, 2017, 120(1-2), 309-321. http://dx.doi.org/10.1016/j. marpolbul.2017.05.042. PMid:28535958.

Received: 14 June 2019 Accepted: 21 February 2020

Associate Editors: André Megali Amado, Joyce Andreia dos Santos, Rafael Marques Almeida, Simone Jaqueline Cardoso. 